\title{
UČINKOVITO ZAGOTAVLJANJE VOJAŠKIH ZMOGLJIVOSTI
}

\section{EFFECTIVE PROVISION \\ OF MILITARY CAPABILITIES}

Professional article

Povzetek Vladam pri uresničevanju nacionalnovarnostne in obrambne politike že od nekdaj enega največjih izzivov predstavlja, kako zagotoviti vojaške zmogljivosti, med katere štejemo tako osebje, opremo in infrastrukturo kot tudi doktrino delovanja, organizacijo, usposabljanje in podporo. Na novo varnostno okolje se države praviloma odzovejo z oblikovanjem nacionalnih oboroženih sil, ki so se z novimi zmogljivostmi sposobne zoperstaviti trenutnim in novim grožnjam. Učinkovito zagotavljanje nacionalnih vojaških zmogljivosti pa zahteva načrten pristop, ki poleg doseganja strateških zahtev upošteva še razpoložljive vire. V Republiki Sloveniji so se v zadnjih desetih letih precej izboljšala institucionalna pravila, ki spodbujajo učinkovitejše zagotavljanje vojaških zmogljivosti. Kljub temu pa se na področju obrambnega planiranja in načrtovanja ter vojaških investicij še vedno soočamo s številnimi pomanjkljivostmi, ki jih bo v prihodnje treba odpraviti.

Ključne Vojaške zmogljivosti, učinkovitauporaba virov, obrambno planiranje in načrtovt besede nje, vojaške investicije.

Abstract One of the biggest challenges for national governments in implementing national security and defence policy has always been the provision of military capabilities, which include personnel, equipment and infrastructure, as well as doctrine of operation, organization, training and support. States generally respond to new security environment by creating national armed forces, which have new capabilities available to withstand current and emerging threats. An effective provision of national military capabilities, however, requires a systematic approach which, in addition to strategic requirements, takes into account the available resources. In the Republic of Slovenia, the institutional rules which encourage more efficient provision of military capabilities have substantially improved in the last ten years. Nevertheless, we still face a number of deficiencies in the field of defence planning and military investments, which should in the future be corrected. 


\section{Key words Military capabilities, effective use of resources, defence planning, military investments.}

Uvod Spreminjajoče se varnostno okolje spodbuja države k transformaciji vojaških zmogljivosti, ki so potrebne za soočanje s kompleksnimi izzivi in grožnjami varnosti. Hkrati posamezna država kot referenčna točka kolektivne identitete zaradi globalizacijskih procesov izgublja svoj pomen. Zato tudi razvoj nacionalnih oboroženih sil v tehnološki, ekonomski in sociopolitični luči sledi logiki ločevanja in varčevanja. Internacionalizacija in globalizacija silita tudi take institucije, kot so oborožene sile, k upoštevanju konkurenčnosti in učinkovitosti, saj drugače dolgoročno ne bodo preživele. Zato se morajo tudi oborožene sile, kljub dejstvu, da je njihova glavna naloga »proizvajati« nacionalno obrambo, ki je zaradi državnega monopola nad sredstvi prisile, in dejstva, da je obramba javna dobrina ${ }^{1}$, torej monopolna funkcija države, začeti obnašati kot subjekt na trgu². Za oborožene sile to pomeni, da morajo izboljšati predvsem ekonomsko učinkovitost zagotavljanja svojih zmogljivosti.

Namen tega članka torej ni opredelitev konkretnih nacionalnih vojaških zmogljivosti, kar je v domeni vojaških strokovnjakov, temveč ugotoviti, kako lahko oborožene sile čim učinkoviteje uporabijo razpoložljive nacionalne vire ${ }^{3}$ za doseganje načrtovane vojaške moči oziroma širše zagotavljanje nacionalnovarnostnih ciljev, ter preveriti, kako učinkovita je pri zagotavljanju svojih vojaških zmogljivosti Republika Slovenija.

V članku bom tako najprej teoretično opredelil ekonomsko učinkovito uporabo javnih in še posebej vojaških virov. Na podlagi tega bom s pomočjo empirične analize ocenil učinkovitost institucionalne ureditve sistema obrambnega planiranja in načrtovanja ${ }^{4}$ ter vojaških investicij v Republiki Sloveniji. Čeprav je to področje v

\footnotetext{
Za javne dobrine je značilno, da poraba posameznika ne zmanjšuje možnosti drugih porabnikov, da trošijo to dobrino in da porabe take dobrine ni mogoče onemogočiti ali prepovedati. Poleg tega so javne dobrine povezane tudi s tako imenovanim zastonjkarskim problemom (free-rider problem), ki ga reši država tako, da z davki zbere ustrezno količino denarja za financiranje optimalne količine javne dobrine (Kennedy, 1975: 40, 41, Tajnikar, 1993: 352).

2 Do take ugotovitve je že v 18. stoletju prišel britanski moralni filozof in ekonomist Adam Smith (2010), ki se je ukvarjal tudi z ekonomskimi implikacijami vojaških sistemov. Temeljno ekonomsko načelo, ki ga je zagovarjal, je bilo, da gre družbi najbolje takrat, ko je delitev dela organizirana na načelu specializacije glede na komparativne stroškovne prednosti. Zato tudi državne institucije ne smejo zapravljati omejenih nacionalnih virov, kajti le tako lahko prispevajo $k$ ustvarjanju dodane vrednosti. To pa je po njegovem prepričanju pomenilo, da delitev dela, prostovoljnost in specializacija predstavljajo temeljna načela tudi za vojaško proizvodnjo nacionalne varnosti.

3 Z ekonomskega vidika nacionalne vire v bistvu sestavljajo delo, kapital in zemlja oziroma naravna bogastva. Posledično med vojaške vire uvrščamo posameznike, ki opravljajo različne vrste vojaške službe, vojaške izdatke, vojaško opremo in oborožitev ter vojaško infrastrukturo.

4 Kljub temu, da sta pojma planiranje in načrtovanje v slovenskem jeziku sopomenki (Slovenski pravopis, 2003), pa s strokovnega vidika ločimo obrambno planiranje in obrambno načrtovanje. (1) Obrambno planiranje je tako razvojno planiranje, ki načeloma zajema srednjeročno in dolgoročno plansko obdobje. Posebna oblika obrambnega planiranja je tudi t. i. poslovno planiranje (budgeting), ki je namenjeno predvsem povezavi in operacionalizaciji srednjeročnih planskih dokumentov v vsakoletne proračune. (2) Obrambno načrtovanje (operativno planiranje) pa se nanaša na izvedbene aktivnosti, saj zajema izdelavo in dopolnjevanje obrambnih načrtov odzivanja na krize kot del kriznega upravljanja in planiranje delovanja. Obrambno načrtovanje pokriva bolj kratkoročno plansko obdobje.
} 
zadnjih desetih letih doživelo velik razvoj, bom v sklepu podal še svoje videnje za nadaljnje izboljšanje učinkovitosti planiranja, načrtovanja in stvarnega zagotavljanja predvsem tistega dela vojaških zmogljivosti, ki se pridobi z investicijami.

\section{VOJAŠKE ZMOGLJIVOSTI}

Koncept vojaških zmogljivosti je sorazmerno nov pojem, za katerega še ni enotne definicije. Tako ameriško ministrstvo za obrambo opredeljuje vojaške zmogljivosti kot sposobnost doseganja določenega vojnega cilja. Pri tem po njihove vojaške zmogljivosti vključujejo štiri bistvene komponente: strukturo sil (število, obseg, struktura in formacije oboroženih sil, vojaška oprema in oborožitev), modernizacijo (tehnična sofisticiranost enot, vojaške opreme in oborožitve), pripravljenost (sposobnost zagotavljanja zmogljivosti za izvajanje določenih nalog) in vzdržljivost (sposobnost vzdrževanja nujne ravni in trajanja operativnega delovanja za doseganje vojaških ciljev). (Military Capabilities Definition, 2008)

Hinge $(2000,7)$ k temu dodaja, da so pri tem vojaške zmogljivosti oblikovane na podlagi predhodnih razpoložljivih virov za njihovo gradnjo, konteksta oziroma ocene strateškega okolja in stopnje ogroženosti ter predvidenih učinkov njihove uporabe, ki se kažejo v pravilih delovanja.

Moroney in drugi (2007, 44-45) pa menijo, da vojaške zmogljivosti obsegajo elemente, kot so doktrina, organizacija in vodenje (strateške smernice, struktura, poveljevanje in nadzor, taktična navodila za delovanje, mednarodne izkušnje itn.), kadri in finančna sredstva (obseg ustreznega kadra, javne finance, obrambni proračun oziroma izdatki), oprema (vojaška oprema in oborožitev, ki sta primerni za delovanje v okolju z vsemi mogočimi scenariji), usposabljanje (vojaška izobrazba, izurjenost in usposobljenost, sodelovanje na vajah itn.) ter infrastruktura (poveljstva, vojaške baze, vadišča, strelišča itn.).

Vojaške zmogljivosti torej obsegajo veliko več kot samo sile oziroma enote ali opremo oziroma oborožitev. Razumljene morajo biti z vidika ključnih elementov, ki prispevajo k vojaškim zmogljivostim: doktrine, organizacije, kadrov, voditeljstva, opreme in oborožitve, usposabljanja, infrastrukture in podpore. Večina oboroženih sil po svetu uporablja ta pristop in skrbi, da so med navedenimi ključnimi elementi investicije uravnotežene. Noben izmed elementov ni obravnavan kot pomembnejši. Na primer, slabo usposobljeno vojaško osebje, ki z neprimerno doktrino uresničuje svoje poslanstvo z najsodobnejšim orožjem, bo doživelo neuspeh celo proti slabše opremljenemu nasprotniku, ki je bolje usposobljen in ima dobro doktrino. Upravljanje vojaških zmogljivosti zato zahteva načrten pristop, ki upošteva vse navedene elemente napram strateškim zahtevam in razpoložljivim finančnim sredstvom (Managing Military Capability, 2005).

Poudariti moram, da v tem članku vseh elementov koncepta vojaških zmogljivosti ne bom obravnaval enako. Moja empirična analiza bo namreč usmerjena $\mathrm{v}$ 
institucionalno ureditev sistema obrambnega planiranja in načrtovanja ter vojaških investicij v Republiki Sloveniji, ki vključuje predvsem zagotavljanje vojaške opreme, oborožitve in vojaške infrastrukture ter delno tudi podporo in usposabljanje. Zato se tudi ne bom poglobljeno ukvarjal z vprašanji zagotavljanja primernega vojaškega osebja in organizacijske strukture oboroženih sil, oblikovanja strateških in doktrinarnih dokumentov ter taktičnega vodenja.

\section{UČINKOVITA UPORABA VOJAŠKIH VIROV}

Ker $\mathrm{v}$ delovanje javnega sektorja $\mathrm{v}$ primerjavi $\mathrm{z}$ delovanjem zasebnega nista vgrajena mehanizma trga in konkurence, je učinkovita uporaba javnih virov velik problem. Medtem ko so zaradi težnje po dobičku in grožnje bankrota zasebna podjetja nenehno pod pritiskom iskanja donosnih inovacij in učinkovitih metod proizvodnje, pa nasprotno znotraj javnega sektorja takih teženj in groženj, ki bi vodile $\mathrm{k}$ iskanju donosnih inovacij in učinkovitih metod proizvodnje, navadno sploh ni (Bergstrometal, 1986). Ker ni pravih meril oziroma so objektivna merila učinkovitosti pomanjkljiva, se $\mathrm{v}$ javnem sektorju pri uporabi virov pogosto srečujemo $\mathrm{z}$ vplivom osebnih lastnosti in neekonomskih preferenc uradnikov, ki o tem odločajo, ali skladno s Parkinsonovim zakonom, ki pravi, da se delo opravi tako, da se zapolni čas, ki je na voljo za njegovo dokončanje $\mathrm{e}^{5}$.

Čeprav se zdi, da bi bilo mogoče učinkovitejšo uporabo virov v javnem sektorju doseči le z njegovo popolno privatizacijo, pa ni tako. Že Adam Smith, oče ekonomskega liberalizma, je namreč ugotavljal, da je država najbolj odgovorna za organiziranje in vzdrževanje tistih javnih institucij in služb, ki največ prispevajo k javnemu dobru $^{6}$ (Smith, 2010). V javnem sektorju, v katerem se je v zadnjih sto letih poraba relativno povečala za nekajkrat ${ }^{7}$, učinkovitejšo uporabo virov lahko dosežemo tudi z izboljšanjem institucionalnih pravil za spodbujanje učinkovitosti, in sicer z uporabo kvantitativnih ekonomskih analiz za določanje alokacije javnih virov in s povečanjem zavedanja, da so vse javne odločitve tudi ekonomske (Cauleyetal, 1986).

(1) Najbolj skrajni predlogi za izboljšanje institucionalnih pravil spodbujajo neposredno vključevanje tržnih oziroma cenovnih mehanizmov v odločanje znotraj javnega sektorja. Nekoliko manj ambiciozni so predlogi, ki so usmerjeni v izboljšanje proračunskih in računovodskih metod, zagotavljanje primernejših spodbud in reorganizacijo procesa odločanja (Leitzel, 1992). (2) S kvantitativnimi ekonomskimi metodami,

\footnotetext{
Več glej Parkinson, 1957.

6 Po mnenju Smitha (2010, str. 5 ) morajo države tako poskrbeti za "pospešen blagovni promet družbe ter spodbujati izobraževanje ljudi«, delovati po načelu zakonitosti, z drugimi besedami veljati morajo pravna pravila (v javni upravi, policiji in sodstvu), in zagotavljati ustrezno infrastrukturo (ceste in železnice), obrambo ter izobrazbo.

7 Pred prvo svetovno vojno se je poraba, namenjena javnim dobrinam, v posameznih državah gibala od 10 do $15 \%$ BDP. Do šestdesetih let prejšnjega stoletja se dvigne na $30 \%$ BDP. Najbolj očitno in strmo vzpenjanje javne porabe pa je mogoče zaznati v naslednjih dveh desetletjih, tako da večina industrijsko razvitih držav od osemdesetih let prejšnjega stoletja dalje namenja kar približno 50 \% BDP za javne dobrine (Stark, 2007).
} 
kot so krivulja proizvodnih možnosti ${ }^{8}$ in indiferentne krivulje ${ }^{9}$ na eni strani ter krivulja enakega produkta ${ }^{10}$ in premica alternativnih omejitev ${ }^{11}$ na drugi, je mogoče določiti vsaj učinkovito, če že ne kar optimalno uporabo virov. Pri tem pa se je treba zavedati, da so kvantitativna ekonomska razmerja v javnem sektorju zelo kompleksna, saj praviloma vključujejo številna različna tehnološka področja ter številne operativne in ekonomske dejavnike (Hitch, 1986). (3) Do izboljšanja ekonomskega razumevanja narave problema pa $\mathrm{v}$ resnici pridemo predvsem s postavljanjem pravih vprašanj pri uporabi javnih virov. Z upoštevanjem vseh mogočih alternativ in uporabo razumskih meril pri odločanju se verjetnost učinkovite uporabe virov izboljša celo v primerih, ko je razmislek o tem predvsem intuitiven (Turpin, 1989).

Pri uporabi vojaških virov se odločevalci zelo pogosto odločajo za določanje prednostnega vrstnega reda. To še posebej velja za odločitve o porabi točno določenih finančnih sredstev, pri čemer se potrebne vojaške zmogljivosti rangirajo glede na nujnost. Rezultat tega je seznam vseh želenih zmogljivosti, od tistih, ki so najbolj nujne, do tistih, ki to niso. Na prvi pogled se ta pristop zdi zelo premišljen, vendar pa se ob njegovi uporabi hitro začnejo porajati številna vprašanja o tem, kako uporabiti tak vrstni red. Če to pomeni, da se finančna sredstva porabijo najprej za nakup vseh najnujnejših zmogljivosti in šele nato drugih, $v$ čem je potem sploh smisel rangiranja vseh preostalih, manj nujnih zmogljivosti. Če tak seznam pomeni, da bi morali porabiti več finančnih sredstev za nujnejše zmogljivosti in manj za ne tako nujne, pa se zaradi dejstva, da so stroški zagotovitve posameznih zmogljivosti različni ${ }^{12}$, zatakne pri vprašanju, koliko enot posameznih zmogljivosti sploh zagotoviti. Z določanjem prednostnega vrstnega reda torej ni mogoče rešiti vprašanja alokacije virov. V skrajnem primeru lahko zato tak pristop privede celo do sprejemanja napačnih odločitev o uporabi vojaških virov (Ganser, 1989).

Učinkovito uporabo vojaških virov lahko tako kljub nekaterim pomislekom ${ }^{13}$ dosežemo predvsem z uporabo ekonomske izbire. Bistven pomen uporabe ekonomske izbire pri odločitvah o učinkoviti uporabi vojaških virov izhaja iz primerjave vseh ustreznih

\footnotetext{
Krivulja proizvodnih možnosti oziroma transformacijska krivulja na splošno prikazuje različne količine dveh dobrin, ki ju lahko proizvajamo z danimi produkcijskimi sredstvi. Točke na krivulji predstavljajo menjavo med dvema dobrinama in jih imenujemo oportunitetni stroški oziroma marginalna stopnja transformacije (Samuelson, 1992).

9 Indiferentna krivulja na splošno prikazuje kombinacije vseh dobrin, ki potrošniku prinašajo enako zadovoljstvo. Višje ležeče indiferentne krivulje predstavljajo kombinacije dobrin, ki dajejo večje zadovoljstvo in obratno (prav tam).

${ }^{10}$ Krivulja enakega produkta ali izokvanta prikazuje vse kombinacije produkcijskih faktorjev, s katerimi proizvedemo enako količino produkta (prav tam).

${ }^{\prime \prime}$ Premica alternativnih omejitev oziroma krivulja menjave kaže način, s katerim sta lahko vložka zamenjana ob predpostavki, da je celotni proračun nespremenjen. Položaj premice določa velikost potrošnikovega dohodka in višino cen obeh dobrin. (prav tam).

${ }_{12}$ Če je cena na enoto zmogljivosti, ki je na seznamu opredeljena kot nujna, nižja od cene na enoto zmogljivosti, ki ni tako nujna, je za nakup nujnejših zmogljivosti potrebna sorazmerno manjša količina finančnih sredstev kot za nakup ne tako mujnih in obratno.

${ }^{13}$ Med številnimi posamezniki velja prepričanje, da je ekonomska izbira pri odločanju o uporabi vojaških virov nepotrebna, saj je nacionalna obramba najvišja vrednota, ki jo je treba zagotoviti za vsako ceno. Nekateri so tudi mnenja, da ekonomska učinkovitost pomeni le poceni oborožene sile in majhen obrambni proračun. Drugi spet nasprotujejo ekonomski izbiri, ker menijo, da sili oborožene sile v nakupe poceni opreme oziroma $v$ uporabo zastarele (Hitch, 1986).
} 
alternativ, in sicer z vidika ciljev, ki jih lahko te dosežejo, s stališča stroškov, ki jih ustvarijo, in z vidika uporabe primernega ekonomskega merila za izbiro najboljše alternative. Za doseganje učinkovite uporabe vojaških virov s pomočjo ekonomske izbire tako vedno, ne glede na to, ali za rešitev potrebujemo napredno matematiko ali le preprosto logiko, potrebujemo cilje, alternative, stroške, model in merila (Hitch, 1986).

(1) Pri vsaki uporabi vojaških virov se je treba najprej vprašati, kakšne vojaške cilje poskušamo z njimi doseči. Določitev ciljev je izredno pomembna, saj napačna izbira pomeni, da se celotna analiza ukvarja z nepravim vprašanjem. (2) Izbrani vojaški cilji so lahko doseženi z izbiro različnih vojaških virov. Pri tem je ena največjih težav zagotovilo, da so v analizo vključene vse dobre alternative ${ }^{14}$. (3) Vsaka alternativa za dosego vojaških ciljev uporablja vire, ki imajo svojo ceno. Tako nastali stroški so v vse ekonomske analize vključeni kot negativne vrednosti v primerjavi z doseženimi cilji, ki predstavljajo pozitivne vrednosti. (4) Model je abstraktna predstavitev dela resničnega sveta ${ }^{15}$, ki nam pomaga dojemati, upravljati in napovedovati značilna razmerja iz stvarnosti. Ekonomska izbira učinkovite uporabe vojaških virov od modelov zahteva, da sledijo razmerjem med vložki (viri oziroma stroški) in rezultatom (cilji) vsake primerjane alternative, s čimer napovedo pomembne posledice izbire. (5) Merilo je test, s katerim raje izberemo neko alternativo. Izbira primernega merila je pogosto osrednja težava oblikovanja ekonomske izbire učinkovite uporabe vojaških virov. Na splošno velja, da je optimalna izbira tista, ki ustvarja največ pozitivnih vrednosti (ciljev) v primerjavi z negativnimi (uporabljeni viri oziroma stroški). Ker cilji in stroški navadno nimajo skupne mere, se moramo pri ekonomskih analizah pogosto zadovoljiti s približkom idealnega merila, ki nam omogoča presoditi, katera izbira je boljša, ne pa, katera je najboljša (Hitch, 1986).

Poleg teh dveh pristopov pa lahko odločitev o uporabi vojaških virov temelji tudi na tako imenovanih zahtevah. To še posebej velja za razvoj popolnoma nove generacije vojaških zmogljivosti, pri katerem prihaja do pomanjkanja informacij oziroma ocen o posameznih elementih ekonomske izbire (predvsem o uresničljivih ciljih in resničnih stroških). Odločevalci tako najprej proučijo problem, nato oblikujejo projekt, kako naj bi problem rešili, in določijo zahteve, ki izhajajo iz projekta. Sledi preverjanje možnosti izvedbe takega projekta, ki vključuje tako ugotavljanje izvedljivosti tehničnih zahtev kot razpoložljivosti finančnih sredstev in drugih virov. Če je projekt izvedljiv, sledi njegova izvedba, če ne, ga je treba prilagoditi. Ker tak pristop temelji predvsem na izpolnjevanju tehničnih zahtev, stroškovni vidik izbire uporabe vojaških virov pa je omejen zgolj na izločanje tistih projektov, ki presegajo razpoložljiva finančna sredstva ${ }^{16}$, je izbira »najboljše« alternative lahko predobra za doseganje zahtevanih ciljev in tako ni nujno, da je ekonomsko optimalna (McNaugher, 1990).

\footnotetext{
${ }^{14}$ Iznajdba novih in boljših alternativ za doseganje zastavljenega cilja je najpomembnejši stranski proizvod pri uporabi ekonomske izbire za določanje učinkovite uporabe virov (McGuire, 1985).

${ }^{15}$ Modeli precej odmišljajo stvarnost, saj se osredotočajo samo na tisto, kar je pomembno za rešitev problema, s katerim se ukvarjajo (Dasgupta, 1992).

${ }^{16}$ Ker se za zagotavljanje novih vojaških zmogljivosti pogosto zahteva le od 10- do 25-odstotno povečanje razpoložljivih proračunskih sredstev, pristop, ki temelji na t. i. zahtevah, zaradi finančne neizvedljivosti izloči le redke projekte (McNaugher, 1990).
} 


\section{ZAGOTAVLJANJE ZMOGLJIVOSTI SLOVENSKE VOJSKE}

\subsection{Planiranje in načrtovanje vojaških zmogljivosti}

Za učinkovito zagotavljanje vseh vojaških zmogljivosti sta najprej potrebni ustrezni planiranje in načrtovanje, ki ju lahko v metodološkem smislu razumemo kot proces določanja ciljev, razvijanja alternativnih poti za njihovo uresničitev, ocenjevanja in izbire med njimi ter obdelave izbrane alternative (ali alternativ, če jih je več) v plane, načrte, politike, programe in predračune (Možina in drugi, 1994).

V Republiki Sloveniji obrambno planiranje in načrtovanje predstavljata pomembno orodje države za oblikovanje zmogljivosti obrambnega sistema oziroma obrambnih sil in za razvoj nacionalne obrambne infrastrukture. Obrambno planiranje in načrtovanje sta sestavni del procesa, s katerim lahko vlada opravlja nadzor in usklajuje planiranje in načrtovanje, vzdrževanje in racionalno porabo obrambnih virov za razvoj nacionalnega obrambnega sistema (MO RS, 2004).

Planiranje in načrtovanje $\mathrm{v}$ obrambnem sistemu Republike Slovenije urejata predvsem dva predpisa. Prvi je Zakon o obrambi, ki v 82. členu predpisuje: »Državni zbor določa temeljne usmeritve za organizacijo in izvajanje obrambe in pri tem zlasti: sprejema splošne dolgoročne programe razvoja in opremljanja Slovenske vojske« (DZRS, 2004). Drugi predpis, ki ureja področje obrambnega planiranja in načrtovanja, pa je Pravilnik o planiranju na Ministrstvu za obrambo, ki v 1. členu določa, da planiranje obsega planiranje zmogljivosti (usmerjeno v učinke in ne zgolj sile oziroma enote, temelji na povezavi posameznih planskih področij), planiranje delovanja (obrambno načrtovanje in operativno planiranje) ter poslovno planiranje. V istem členu je določeno, da se planiranje na Ministrstvu za obrambo izvaja za dolgoročno, srednjeročno in kratkoročno obdobje (MO RS, 2005).

Za izvajanje, razvoj in nenehno izboljševanje planiranja in načrtovanja je na Ministrstvu za obrambo odgovoren Direktorat za obrambno politiko (DOP). Vodje notranjih organizacijskih enot in predstojniki organov v sestavi so odgovorni za izvedbo, razvoj in nenehno izboljševanje planiranja oziroma načrtovanja ter za doseganje načrtovanih ciljev notranjih organizacijskih enot in organov v sestavi, ki jih vodijo, pri čemer morajo upoštevati razpoložljive vire in sprejemljiva tveganja (MO RS, 2005).

Obrambno planiranje in načrtovanje sta razdeljeni na štiri ravni ${ }^{17}$. Planiranje zmogljivosti ${ }^{18}$ je prepuščeno prvi ravni, ki jo sestavljajo: načelnik Generalštaba Slovenske vojske (GŠSV), generalni direktor Uprave Republike Slovenije za zaščito in reševanje, direktor Obveščevalno varnostne službe, glavni inšpektor za obrambo, glavni inšpektor za varstvo pred naravnimi in drugimi nesrečami, generalni direktorji

\footnotetext{
17 Več glej MO RS, 2005.

${ }^{18}$ Z načrtovanjem zmogljivosti se zagotavljajo ustrezne zmogljivosti države, potrebne za uresničitev interesov in ciljev Republike Slovenije na področjih obrambe ter zaščite in reševanja, tako do nacionalne kot tudi do kolektivne varnosti znotraj zavezništva (MO RS, 2005).
} 
direktoratov in generalni sekretar ter vodja Kabineta ministra. Na tej stopnji se pripravljajo strateški dokumenti, kot so Strateški pregled obrambe (SPO) ${ }^{19}$, Splošni dolgoročni program opremljanja in razvoja Slovenske vojske (ReSDPRO) ${ }^{20}$ ter Srednjeročni obrambni program (SOPR) $)^{21}$.

DOP v sodelovanju z drugimi organizacijskimi enotami na prvi ravni planiranja in načrtovanja usklajuje pripravo strateškega pregleda obrambe, pripravi zaključno poročilo in ga posreduje ministru. Na prvi ravni DOP v sodelovanju z organizacijskimi enotami praviloma vsaka štiri leta za obdobje najmanj dvanajstih let pripravi predlog dolgoročnega obrambnega plana, ki je podlaga za spreminjanje vojaških zmogljivosti. Na podlagi predlogov zmogljivosti, obrambne strategije, dolgoročnega obrambnega plana, sprejetih mednarodnih obveznosti države, letnih poročil ministrstva, proračunskih okvirov in ciljev države pripravi DOP predlog smernic za pripravo srednjeročnega programa, ki opredeljujejo nacionalnovarnostne potrebe, izzive na obrambnem področju, predvsem pa predvidene razpoložljive vire za načrtovano obdobje, navadno šestih let. DOP v sodelovanju z organizacijskimi enotami na prvi ravni planiranja in načrtovanja $\mathrm{v}$ letu pred začetkom sprejemanja proračuna pripravi tudi predlog srednjeročnega programa, ki je podlaga za izdelavo poslovnega plana, s katerim se določijo cilji in naloge organizacijskim enotam, odgovornosti za naloge, roki in viri za njihovo izvedbo ter vrednosti kazalnikov za merjenje stopnje uresničevanja ciljev in nalog.

GŠSV pripravi predlog vojaških zmogljivosti, ki predstavlja vojaški nasvet in obsega predlog vojaških zmogljivosti za izvedbo zastavljenih ciljev in nalog Slovenske vojske. Na podlagi predloga vojaških zmogljivosti, prioritet ministra in vlade ter razpoložljivih finančnih in kadrovskih virov DOP pripravi smernice. Pri tem naj bi GŠSV na podlagi usmeritev Ministrstva za obrambo, veljavne ocene ogroženosti, opredeljenih nalog Slovenske vojske in izkazanih potreb zavezništev (Nata in Evropske unije) pripravljal tudi analize in planske scenarije ter predloge za razvoj posameznih zmogljivosti in Slovenske vojske kot celote. Ob upoštevanju meril zmogljivosti (capability statements) po posebni metodologiji pripravlja koncepte in študije posameznih enot ter izvedbene načrte za razvoj in doseganje končnih operativnih zmogljivosti teh enot. Te potrebe Slovenske vojske GŠSV posreduje Ministrstvu za

\footnotetext{
19 Strateški pregled obrambe je pregled zmogljivosti, delovanja in upravljanja obrambnega sistema z vidika njegove ustreznosti, primernosti in učinkovitosti ter je podlaga za pripravo dolgoročne vizije nadaljnjega razvoja obrambnega sistema (prav tam).

${ }^{20} Z$ dolgoročnim obrambnim planom se določa smer razvoja obrambnega sistema, s katerim se uresničuje obrambna strategija v dolgoročnem obdobju, spreminjanje vojaških zmogljivosti ter strukture in pripravljenosti Slovenske vojske (prav tam)

${ }^{21}$ Srednjeročni obrambni program, ki prikazuje razvoj ter predvideno stanje zmogljivosti na koncu vsakega leta, praviloma za obdobje šestih let, vsebuje: ključne elemente obrambne politike v srednjeročnem obdobju, prikaz razvoja obrambnega sistema, poslanstvo in naloge obrambnega sistema, razvojne cilje, razvojne prioritete, organizacijsko strukturo ministrstva, obseg in strukturo Slovenske vojske, glavne programe opremljanja obrambnega sistema v srednjeročnem obdobju, sistem upravljanja človeških virov, kadrovsko strukturo, makroekonomska gibanja in predvidevanja ter projekcijo obrambnih izdatkov in strukturo finančnih virov. Srednjeročni obrambni program predstavlja tudi podlago za pripravo odgovorov na Natov vprašalniko obrambnem načrtovanju (Defence Planning Capability Survey-DPCS) in podlago za pripravo odgovorov na Vprašalnik za globalni cilj Evropske unije (Headline Goa lQuestionnaire - HGQ) (prav tam).
} 
obrambo in Vladi RS. O zagotovitvi virov za razvoj Slovenske vojske in s tem posameznih zmogljivosti odloča vlada s sprejemom SOPR in proračunov za posamezna planska obdobja.

Tak sistem obrambnega planiranja in načrtovanja in z njim tesno povezanega planiranja in načrtovanja vojaških zmogljivosti, ki temelji na povezanosti posameznih planskih področij (planiranje sil, virov, oborožitve, logistike itn.), torej vedno išče načine, kako zagotoviti potrebne zmogljivosti s čim manjšim obsegom virov oziroma dovolj racionalno in učinkovito. Vseeno pa zaradi pomanjkljivosti, kot so: (1) nepovezanost nacionalnovarnostnega sistema in zaradi nje nevključenost drugih državnih obveščevalnih in varnostnih institucij (npr. Slovenske obveščevalne agencije, Policije itn.) v pripravo ocene ogroženosti; (2) neopredelitev obveznosti, ki jih imajo pri obrambnem načrtovanju posamezne organizacijske enote Ministrstva za obrambo druga do druge; (3) prepočasna odzivnost na spremembe varnostnega okolja in razpoložljivih finančnih sredstev; (4) napačna presoja o sredstvih, ki so potrebna za zagotovitev posameznih vojaških zmogljivosti, in (5) pomanjkanje nekaterih strateških dokumentov, kot so vojaška strateška ocena oziroma vojaška strateška priporočila, v Republiki Sloveniji še vedno ni celovitega sistem obrambnega planiranja in načrtovanja, ki bi omogočil ne le učinkovito, temveč res optimalno zagotavljanje vojaških zmogljivosti.

\subsection{Vojaške investicije}

Medtem ko z obrambnim planiranjem in načrtovanjem nastanejo programi za oblikovanje potrebnih vojaških zmogljivosti, se velik del vojaških zmogljivosti, med katere se uvrščajo predvsem oprema, oborožitev in infrastruktura, vedno bolj pa tudi podpora in usposabljanje, $\mathrm{v}$ resnici zagotovi šele $\mathrm{z}$ njihovim nakupom oziroma $\mathrm{z}$ investiranjem vanje. Pri tem so vojaške investicije praviloma izvedene na podlagi neposrednih pogajanj s favoriziranim ponudnikom ali s pomočjo konkurence, ki temelji na ceni in drugih necenovnih merilih (Sandler, 1995).

V Republiki Sloveniji se izvajata dve vrsti vojaških investicij, ki sta odvisni predvsem od predmeta naročila. Poleg klasičnih javnih naročil, ki pridobivajo na pomenu tudi na obrambnem področju ${ }^{22}$, Ministrstvo za obrambo tako predvsem za zagotavljanje vojaških zmogljivosti uporablja tudi tako imenovana obrambna in zaupna naročila.

Vojaške investicije v Republiki Sloveniji urejata dva predpisa. Prvi je Zakon o javnem naročanju (ZJN-2), ki je namenjen nabavi blaga, oddaji gradenj in naročanju storitev, ki jih izvajajo številni proračunski uporabniki (ministrstva, občine, javna podjetja in zavodi ter še nekatere druge osebe javnega prava), zato je v tem pogledu zelo splošen (Podkoritnik, 2006). Zakon o javnem naročanju s predpisovanjem postopkov, določitvijo tehničnih in drugih elementov javnega naročanja, predpisovanjem pogojev za ugotavljanje sposobnosti in meril za sprejem, rokov, objav in sporočanj ter z določitvijo ravnanja v postopkih javnega naročanja poskuša zagotavljati gospodarno

22 Od leta 2007 na Ministrstvu za obrambo število pogodb, ki izhajajo iz javnih naročil, presega število pogodb, ki temeljijo na obrambnih in zaupnih naročilih (Nered, 2010). 
in učinkovito porabo javnih sredstev (DZ RS, 2006). Drugi predpis pa je Uredba o obrambnih in zaupnih naročilih, ki določa naročila na podlagi 296. člena Pogodbe o ustanovitvi Evropske skupnosti23 in zaupna naročila ${ }^{24}$, za katera se ZJN-2 ne uporablja in za katera je treba skladno z uredbo pridobiti predhodno soglasje medresorske komisije (Vlada RS, 2007a). K takim naročilom so povabljena podjetja, ki jim Ministrstvo za obrambo predhodno podeli dovoljenje ali soglasje za proizvodnjo in promet z vojaškim orožjem in opremo, skladno z Uredbo o dovoljenjih in soglasjih za promet in proizvodnjo vojaškega orožja in opreme (Vlada RS, 2003), ter uredbama o spremembah in dopolnitvah Uredbe o dovoljenjih in soglasjih za promet in proizvodnjo vojaškega orožja in opreme (Vlada RS, 2005 in 2007b) ${ }^{25}$. Leta 2008 pa je bil sprejet še nov Pravilnik o postopkih oddaje obrambnih in zaupnih naročil na Ministrstvu za obrambo, ki poleg postopka povpraševanja pri enem ponudniku in postopka zbiranja povabljenih ponudb predpisuje še postopek zbiranja ponudb z objavo naročila na elektronskem portalu Evropske obrambne agencije ${ }^{26}$.

Vsi procesi, povezani $\mathrm{z}$ načrtovanjem, izvajanjem in spremljanjem postopkov javnega naročanja, se na Ministrstvu za obrambo izvajajo v Direktoratu za logistiko. Poleg tega $\mathrm{v}$ direktoratu potekajo tudi kakovostni prevzemi, procesi normativne oziroma standardne kontrole, procesi materialnega vrednotenja in predaje sredstev $\mathrm{v}$ uporabo končnemu uporabniku oziroma predlagatelju naročila, gospodarjenje $\mathrm{z}$ nepremičninami, ki vključuje javna naročila s področja gradenj, ter investicijsko in redno vzdrževanje infrastrukture. V Slovenski vojski, ki je pristojna predvsem za uporabno logistiko ${ }^{27}$, pa se praviloma izvajajo le postopki oddaje javnih naročil manjše vrednosti, ki so omejena $\mathrm{z}$ razpoložljivimi finančnimi sredstvi, določenimi $\mathrm{v}$ načrtu nabav in gradenj.

Za učinkovitejše izvajanje investicij je bila na Ministrstvu za obrambo sprejeta tudi uredba o metodologiji za pripravo in obravnavo investicijske dokumentacije na obrambnem področju. Uredba, ki pokriva vse investicijske projekte na obrambnem področju, ki se financirajo skladno z javnofinančnimi predpisi, določa metodološke podlage za ocenjevanje in vrednotenje investicij, vrste in vsebinske podrobnosti

\footnotetext{
${ }^{23}$ 296. člen Pogodbe o ustanovitvi Ekonomske skupnosti (1957) med drugim določa, (1) da nobena država članica ni zavezana dajati informacij, za katere meni, da bi bilo njihovo razkritje v nasprotju z bistvenimi interesi njene varnosti; (2) da vsaka država članica lahko v zvezi s proizvodnjo orožja, streliva in vojaških sredstev ali trgovino z njimi sprejme ukrepe, za katere meni, da so potrebni za zaščito bistvenih interesov njene varnosti, vendar pa taki ukrepi ne smejo negativno vplivati na pogoje konkurence na skupnem trgu proizvodov, ki niso izrecno predvideni $v$ vojaške namene.

24 4. člen Uredbe o obrambnih in zaupnih naročilih kot zaupna šteje tista naročila, ki vsebujejo tajni podatek, ki je kot tak določen skladno z Zakonom o tajnih podatkih (Vlada RS, 2007).

${ }^{25}$ Leta 2010 je bilo v Republiki Sloveniji 64 podjetij, ki so imela dovoljenja za promet z vojaškim orožjem in opremo, ter 80 podjetij, ki so imela soglasje za proizvodnjo vojaškega orožja in opreme (Nered, 2010).

${ }_{26}$ Podpisnice meddržavnega režima o obrambnih nakupih so se zavezale, da bodo na elektronskem portalu Evropske obrambne agencije (EBB1) objavile vsa naročila na podlagi 296. člena Pogodbe o ustanovitvi Evropske skupnosti, ki presegajo vrednost milijona evrov. Zaradi tega prihaja na področju vojaških naročil do povečanja konkurenčnosti, saj si naročnik z objavo zagotovi večje število ponudb.

${ }^{27}$ Uporabna logistika obsega aktivnosti, ki se nanašajo na skladiščenje, razdelitev, vzdrževanje in evakuacijo materialnih sredstev, premik moštva in sredstev, vzdrževanje in upravljanje vojaške infrastrukture, finančno podporo in zagotavljanje storitev za zdravstveno oskrbo (Vlada RS, 2006).
} 
investicijske dokumentacije, postopke in udeležence pri pripravi in ocenjevanju investicijske dokumentacije ter merila za ugotavljanje učinkovitosti projektov (Vlada RS, 2009).

(1) Pri ocenjevanju investicij na obrambnem področju se smiselno uporabljajo metodološke podlage, kot so določitev uresničljivih, usklajenih in merljivih ciljev, priprava variant za uresničevanje ciljev, opredelitev vrednostnega in fizičnega obsega stroškov in koristi vsake variante, ugotavljanje občutljivosti variant in izbor najboljše. Pri izračunih in drugih postopkih za presojo upravičenosti projektov na obrambnem področju pa se lahko uporabljajo analize stroškov in koristi, stroškovne učinkovitosti, tveganja, občutljivosti, analiza vplivov in multikriterijska analiza. (2) Med načrtovanjem investicije je treba pripraviti dokument identifikacije investicijskega projekta, predinvesticijsko zasnovo in investicijski program. V drugi fazi se pripravi študija izvedbe nameravane investicije. V fazi izvedbe naročila se pripravi poročilo o izvajanju investicijskega projekta in, če se pokaže potreba, tudi novelacija investicijskega programa. Med izvajanjem naročila pa se pripravi poročilo o spremljanju učinkov investicijskega projekta. (3) Pri ocenjevanju učinkovitosti investicije na obrambnem področju se glede na predvideno vrednost, možnost izračuna finančnih kazalnikov ter vrsto investicije upoštevajo taktično-tehnološka (doseganje zahtevanih obrambnih in vojaških zmogljivosti, izpolnjevanje vojaških standardov, doseganje zahtev pri vzdrževanju itn.), finančna (finančna analiza investicije), ekonomska (poleg neposrednih stroškov in koristi vključujejo tudi posredne vplive na družbo kot celoto) ter razvojna (vključenost znanstvenih institucij in gospodarskih družb obrambne industrije, povečevanje mednarodne konkurenčnosti gospodarstva, vzdrževanje socialne varnosti) merila (Vlada RS, 2009).

Taka institucionalna ureditev izvajanja vojaških investicij omogoča, da so v zagotavljanje velikega dela vojaških zmogljivosti vključeni vsi elementi ekonomske izbire (cilji, alternative, stroški, model in merila), ki omogočajo dosego učinkovite uporabe razpoložljivih virov. Kljub temu pa še posebej pri zapletenejših vojaških investicijah ${ }^{28}$ pogosto prihaja do napak zaradi (1) pomanjkanja strokovnega znanja in nemotiviranosti kadra, (2) premajhne povezanosti in usklajenosti ter neprimerne razmejenosti organizacijskih enot in posameznikov, ki sodelujejo v različnih dejavnostih investicije, (3) pomanjkljive notranje kontrole in premalo učinkovitega upravljanja tveganj, ki pomembno prispevajo $\mathrm{k}$ doseganju zastavljenih ciljev, ter (4) dejstva, da je kakovost odločitev projektne oziroma strokovne skupine v večini primerov zelo odvisna tudi od razmer, v katerih se odloča. Te napake ne samo, da v javnosti ustvarjajo občutek o njihovi neupravičenosti, temveč tudi v resnici zmanjšujejo ekonomsko učinkovitost.

\footnotetext{
${ }^{28}$ Pri mnogih obrambnih investicijah so predmet naročila tehnično zelo zapleteni sistemi, ki zahtevajo poznavanje številnih strokovnih področij. Poleg tega pa vse večje obrambne investicije vključujejo tudi zahtevo po protidobavah, ki še dodatno zapletajo postopke.
} 
Sklep Dejstvo je, da so se v Republiki Sloveniji v zadnjih desetih letih precej izboljšala institucionalna pravila, ki spodbujajo učinkovitejše zagotavljanje vojaških zmogljivosti. Pri tem je poleg povečanja zavedanja, da si ne moremo dovoliti neracionalne porabe javnih virov, pomembno tudi naše vključevanje v evroatlantske integracije. Obrambno planiranje in načrtovanje se tako razvijata skladno s procesom obrambnega planiranja in načrtovanja Nata in Evropske unije. Področje vojaških investicij je precej podvrženo številnim direktivam Evropske unije, ki urejajo javna naročila na splošno oziroma posebej naročanje na področju obrambe in varnosti.

To pa ne pomeni, da smo na področju zagotavljanja vojaških zmogljivosti dosegli maksimum. Številne pomanjkljivosti opozarjajo, da bo treba nadaljnji razvoj sistema obrambnega planiranja in načrtovanja usmeriti predvsem v zagotavljanje celostno bolj usklajene vizije dolgoročnega razvoja nacionalnovarnostnega in obrambnega sistema ter uresničevanje srednjeročnih obrambnih programov s kratkoročnimi oziroma poslovnih planov in njihove usklajenosti s finančnimi načrti Ministrstva za obrambo. Tako se bo zagotavljala še učinkovitejša in bolj pregledna poraba virov tudi pri razvoju zmogljivosti za nacionalno obrambo ter za izpolnitev vojaških obvez do mednarodnih organizacij.

Zaradi vedno večjih zahtev po zmanjševanju javne porabe pa bo treba čim prej odpraviti tudi glavne pomanjkljivosti na področju vojaških investicij. Še posebej za izvedbo zahtevnejših vojaških investicij je projektno vodenje pravi pristop, vendar le ob pogoju, da bodo v prihodnje sistemsko res zagotovljene strokovnost, motiviranost in pristojnosti članov projektnih skupin. Hkrati bo treba nameniti mnogo več pozornosti notranjemu nadzoru, ki bi moral potekati neprestano, med vsemi fazami naročanja. Smiselno bi bilo tudi razmisliti o preoblikovanju meril za ocenjevanje učinkovitosti, tako da bi se zmanjševala tveganost izvedbe investicije in veliko bolj spodbujale neposredne protidobave. Za doseganje večje učinkovitosti je v prihodnje smiselno vojaške investicije izvajati tudi prek vladne agencije za javno naročanje ${ }^{29}$. Vendar pa to velja le za obrambne investicije splošne narave (javna naročila), medtem ko bi moralo investicije v vojaško opremo in oborožitev (obrambna oziroma zaupna naročila) zaradi njihove posebnosti in zahtevnosti še naprej izvajati Ministrstvo za obrambo.

1. Cauley, Jon, Sandler, Todd, in Cornes, Richard, 1986. Nonmarket Institutional Structures: Conjectures, Distribution, and Efficiency, Public Finance. 41-1, str. 153-172.

2. Dasgupta, Dipankar, in Itaya, Jun-chi, 1992. Comparative Statics for the Private Provision of Public Goods in a Conjectural Variations Model with Heterogeneous Agents. Public Finance. 47-1, str. 17-31.

3. Državni zbor RS, 2004. Zakon o obrambi, Uradni list RS, št. 103/2004. Ljubljana: Uradni list RS.

4. Državni zbor RS, 2006. Zakon o javnem naročanju. Uradni list RS, št. 112/2006. Ljubljana: Uradni list RS.

\footnotetext{
${ }^{29}$ Več v Zakonu o javni agenciji za javno naročanje (DZ RS, 2010) in Sklepu o ustanovitvi Javne agencije za javno naročanje RS (Vlada RS, 2010).
} 
5. Državni zbor RS, 2010. Zakon o javni agenciji za javno naročanje, Uradni list RS, št. 59/2010. Ljubljana: Uradni list RS.

6. Gansler, Jacques S., 1980. Affording Defense: The Changes That are Needed. National Contract Management Journal. 23-1, str. 1-22.

7. Hinge, Alan, 2000. Australian Defence Preparedness: Principles, Problems and Prospects: Introducing Repertoire of Missions (ROMINS) a Practical Path to Australian Defence Preparedness. Canberra: Australian Defence Studies Centre.

8. Hitch, Charles J., in McKean, Roland N., 1986.The Economics of Defense in the Nuclear Age. Cambridge: Harvard University Press.

9. Kennedy, Garvin, 1975. The Economics of Defence. London: Faber \& Faber.

10. Leitzel, Jim, 1992. Competition in Procurement. Policy Science. 25-1, str. 43-56.

11. Nered, Igor, 2010. Poslovne priložnosti slovenskih podjetij: novosti na področju obrambnih naročil $v$ RS in možnosti poslovnega sodelovanja v tujini. Predavanje na strokovni konferenci Poslovne priložnosti v Evropi (23. 9. 2010). Gornja Radgona: Pomurski sejem.

12. Managing Military Capability: investing wisely for the future. 2005, http://www.ameinfo. com/54286.html, 24. 5. 2011.

13. McGuire, Martin C., in Groth, Carl H., 1985. A Method for Identifying the Public Good Allocation Process within the Group. Quarterly Journal of Economics. 100, str. 915-34.

14. McNaugher, Thomas L., 1990. Defense Management Reform: For Better or for Worse? Washington DC: Brookings Institution.

15. MilitaryCapabilitiesDefinition.2008. US DepartmentofDefence,http://usmilitary.about. com/od/glossarytermsm $/ \mathrm{g} / \mathrm{m3958.htm,} \mathrm{4.} \mathrm{5.} 2011$.

16. Moroney, Jennifer D. P., Adam Grissom, in Jefferson P. Marquis, 2007. A CapabilitiesBased Strategy for Army Security Cooperation. RAND Corporation.

17. Ministrstvo za obrambo RS, 2004. Strateški pregled obrambe 2002/2003 z vizijo razvoja do leta 2015, št. 802-00-15/2003-19, 12. 3. Ljubljana: MO RS.

18. Ministrstvo za obrambo RS, 2005. Pravilnik o planiranju v MO RS, št. 017-02-15/200331, 23.12. Ljubljana: MO RS.

19. Možina, Stane, in drugi, 1994. Management. Radovljica: Didakta.

20. Parkinson, Northcote C., 1957. Parkinsonфs Law and Other Studies in Administration. Boston: Houghton Mifflin Co.

21. Samuelson, Paul A., in William D. Nordhouse, 1992. Economics - Fourteenth Edition. New York: McGraw-Hill, Inc.

22. Sander, Todd, in Hartly, Keith, 1995. The Economics of Defense. New York: Cambridge University Press.

23. Smith, Adam, 2010. Bogastvo narodov: raziskava o naravi in vzrokih bogastva narodov. Ljubljana: Studia humanitatis.

24. Stark, Jurgen, 2007. Fitforthefuture? Towards a lean and efficientpublic sector.Frankfurt am Main: European Central Bank.

25. Tajnikar, Maks, 1993. Mikroekonomija s poglavji iz teorije cen-druga, popravljena izdaja. Ljubljana: Ekonomska fakulteta.

26. Turpin, Colin, 1989. Government Procurement and Contracts. London: Longman.

27. Vlada RS, 2003. Uredba o dovoljenjih in soglasjih za promet in proizvodnjo vojaškega orožja in opreme. Uradni list RS, št. 18/03. Ljubljana: Uradni list RS.

28. Vlada RS, 2005. Uredba o spremembah in dopolnitvah uredbe o dovoljenjih in soglasjih za promet in proizvodnjo vojaškega orožja in opreme. Uradni list RS, št. 31/05. Ljubljana: Uradni list $R S$.

29. Vlada RS, 2006. Srednjeročni obrambni program 2007-2012. Št. 803-2/2006-58. Ljubljana: $M O R S$. 
30. Vlada RS, 2007a. Uredba o obrambnih in zaupnih naročilih. Uradni list RS, št. 80/2007. Ljubljana: Uradni list RS

31. Vlada RS, 2007b. Uredba o spremembah in dopolnitvah uredbe o dovoljenjih in soglasjih za promet in proizvodnjo vojaškega orožja in opreme, Uradni list RS, št. 113/07. Ljubljana: Uradni list RS.

32. Vlada RS, 2009. Uredba o metodologiji za pripravo in obravnavo investicijske dokumentacije na obrambnem področju. Uradni list RS, št. 9/2009. Ljubljana: Uradni list $R S$.

33. Vlada RS, 2010. Sklep o ustanovitvi Javne agencije za javno naročanje Republike Slovenije. Uradni list RS, št. 86/2010. Ljubljana: Uradni list RS.

34. 1957. Pogodba o ustanovitvi Evropske skupnosti (prečiščena različica). C 321. Bruselj: Uradni list EU.

35. 2003. Slovenski pravopis. Ljubljana: Založba ZRC. 


\section{AMERIŠKI CIVILNO-VOJAŠKI ODNOSI, VOJAK IN DRŽAVA V NOVI DOBI}

Petdeset let po objavi Huntingtonove teorije o civilno-vojaških odnosih sta Suzanne C. Nielsen in Don M. Snider, profesorja z ameriške vojaške akademije West Point, zbrala skupino priznanih strokovnjakov političnih in družbenih ved ter zgodovine s temeljnim namenom: analizirati značilnosti civilno-vojaških odnosov v ZDA ter ugotoviti uporabnost Huntingtonove teorije za proučevanje sodobnih civilno-vojaških odnosov. Z uporabo njegove teorije so proučevali razvoj in stanje ameriških civilno-vojaških odnosov, predvsem v kontekstu dogodkov po 11. 9. 2001 in vojne v Iraku. Vsebina proučevanja so bili odnosi med civilnimi in vojaškimi voditelji, proces sprejemanja odločitev na strateški ravni in vloga vojaškega nasveta, sodoben odnos med družbenim in funkcionalnim imperativom vojske, podrejenost vojske civilnim avtoritetam, značilnosti vojaške profesije in vojaške etike ter odnos med zakonodajno in izvršno vejo oblasti. Knjiga ${ }^{1}$ je nekakšen učbenik, kako se metodološko, analitično in interdisciplinarno lotiti proučevanja, med drugim daje tudi kratek presek razvoja družboslovnih ved.

V knjigi sedemnajst avtorjev z različnim pristopom posreduje poglede na civilno-vojaške odnose v ZDA in ocenjuje vrednost Huntingtonove teorije v tem stoletju. Skupna ugotovitev je, da je tradicija dobrih civilno-vojaških odnosov prekinjena in da se pojavlja potreba po njihovem »popravilu«, predvsem procesa strateškega odločanja in definiranja obrambne politike, odnosov med civilnimi in vojaškimi voditelji ter vloge in kakovosti vojaškega nasveta. Betz se na primer sprašuje o meji med civilno in vojaško sfero in trdi, da objektivni nadzor ni absolutno dober, kot tudi subjektivni ni izključno škodljiv. Podobno Gibson ugotavlja pomanjkljivosti popolne ločenosti civilne in vojaške sfere ter izpostavlja potrebo po spremembi zakonodaje in vedenjskih norm. Kohn se pridružuje Gibsonovem razmišljanju o

Uredila Suzanne C. Nielsen in Don M. Snider, izdal The Johns Hopkins University Press, Baltimore, 2009, 409 strani. 
civilnih in vojaških normah vedenja in se sprašuje o načinih povrnitve zaupanja med civilnimi in vojaškimi voditelji.

Moten s proučevanjem odnosa med obrambnim sekretarjem Rumsfeldom in načelnikom kopenske vojske Shinsekijem analizira razloge za konflikte med civilnimi in vojaškimi voditelji ter kako se jim izogniti. Brooksova ga dopolnjuje $\mathrm{z}$ analizo oblik političnega udejstvovanja generalov in ugotavlja, da posledice niso vedno samo negativne. Burk pa se osredotoča na vprašanje o mejah vojaške poslušnosti in moralnih dilemah izpolnjevanja ukazov.

Feaver in Seeler prek razvoja družbenih ved in analize metodološkega aparata za proučevanje civilno-vojaških odnosov potrjujeta relevantnost Huntingtonove teorije za prihodnje študije. Ugotovitvam se pridružuje Desch, ki se je osredotočil na proučevanje civilno-vojaških odnosov v kontekstu ameriške liberalne tradicije in ugotovil, da je kljub kritikam teorija objektivnega nadzora še vedno najboljši okvir reševanja trenj med liberalno kulturo in konservativnim etosom vojaške profesije. Driver pa raziskuje povezavo med ideologijo in vojaškim profesionalizmom in dokazuje, da ni mogoče trditi, da je vojska prežeta s konservativnostjo in skupno ideologijo, ki izhajata iz profesionalizma, in povzema, da skupne vrednote izhajajo iz družbenih.

Schadlow in Lacquement izpostavljata neprimernost teorije objektivnega nadzora in značilnosti vojske kot »upravljavca nasilja« v kontekstu stabilizacijskih operacij ter potrebe po njenem prilagajanju. Segal in De Angelis na podlagi analize razvoja vojaške profesije ugotavljata šibkosti Huntingtonove teorije v sodobni vojaški organizaciji, v kateri ima podčastniški zbor večjo vlogo kot v njegovem času, ter da govorimo o pojavu civilistov v vojaški organizaciji, ki so tudi »upravljavci nasilja«. O potrebi po prilagajanju vojaške organizacije govori tudi Murray, ki poudarja pomen vojaškega izobraževanja in potreb po intelektualnem razvoju vojaških voditeljev ter s tem povezanih potreb prilagajanja vojaškega izobraževanja sodobnim zahtevam.

Spoznanja in sporočila avtorjev so lahko v pomoč vsem, ki proučujejo civilno-vojaške odnose, civilni nadzor in vlogo vojske v družbi. Čeprav so bili predmet proučevanja ameriški civilno-vojaški odnosi, so ugotovitve univerzalne in govorijo o mogočih odklonih v civilno-vojaških odnosih razvitih demokracij. Knjiga prinaša sporočila, kaj jih povzroča, kako jih prepoznavati in kakšne so posledice. Posreduje tudi napotke za uveljavljanje vojaških in civilnih norm vedenja za dvig ravni civilno-vojaških odnosov v praksi.

Posebej koristne so ugotovitve o današnji primernosti in vrednosti Huntingtonove teorije. Čeprav je bila v zgodovini večkrat kritizirana in tudi v tej knjigi avtorji odkrivajo njene šibkosti, je še vedno izredno dober in uporaben metodološki okvir ter izhodiščna točka za proučevanje sodobnih civilno-vojaških odnosov. Z analizo različnih primerov v praksi avtorji izpostavljajo njene pomanjkljivosti in dajejo napotke, kako se jim izogniti. Opozarjajo predvsem na zmotno razumevanje popolnega ločevanja vojaške in civilne sfere. Skupna ugotovitev je, da so v 21. 
stoletju pomen ravnotežja med družbenim in funkcionalnim imperativom, ki oblikujeta vojsko, odnos med civilnim nadzorom in učinkovitostjo vojske ter značilnosti vojaške profesije in vojaške etike še vedno zelo aktualne in uporabne vsebine Huntingtonove teorije. 